\title{
Dissolved carbon dioxide and methane in the littoral areas of Lake Baikal
}

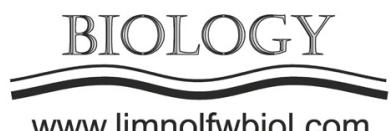

www.limnolfwbiol.com

\author{
Panchenko M.V. ${ }^{1}$, Domysheva V.M. ${ }^{2}$, Pestunov D.A. ${ }^{1 *}$, Sakirko M.V. ${ }^{2}$, \\ Shamrin A.M. ${ }^{1}$, Shmargunov V.P. ${ }^{1}$ \\ ${ }^{1}$ V.E. Zuev Institute of Atmospheric Optics, Siberian Branch of the Russian Academy of Sciences, 1, Academician Zuev square, Tomsk \\ 634055, Russia \\ ${ }^{2}$ Limnological Institute, Siberian Branch of the Russian Academy of Sciences, 3, Ulan- Batorskaya str., Irkutsk, 664033, Russia
}

\begin{abstract}
The results of studying the carbon dioxide and methane spatial distribution in the surface water layer along the coastal zone during the summer periods of 2014, 2016-2019 on Lake Baikal are considered. The partial pressures of gases in the atmosphere and surface waters were continuously measured from the Research Vessel (RV) along the route. It was found that the gas fluxes, determined by the difference in the partial pressures between water and the atmosphere, corresponding to the results of long-term measurements at the Baikal Atmospheric Limnological Observatory (BALO). However, values of concentration and their spatial distribution have a number of features.
\end{abstract}

Keywords: Greenhouse gases, air-water interaction, gas exchange, fluxes, methane source, Lake Baikal

\section{Introduction}

The observed climate changes and an increase in the content of greenhouse gases in the atmosphere necessitate detailed interdisciplinary studies of the carbon cycle in the "atmosphere - underlying surface" system for natural complexes at various scales (from global to local). In the Baikal atmospheric limnological observatory, located on the northwestern coast of Baikal $\left(51^{\circ} 54^{\prime} \mathrm{N}, 105^{\circ} 04^{\prime} \mathrm{E}\right)$, the basic seasonal and diurnal patterns of dissolved carbon dioxide and methane concentrations were determined (Panchenko et al., 2020). Obviously, the applicability of the results obtained in one observation point for the entire littoral zone requires additional studies in order to assess the reproducibility of the process components, primarily, the predominant fluxes direction. According to this task, detailed measurements of the dissolved $\mathrm{CO}_{2}$ and $\mathrm{CH}_{4}$ spatial distributions were carried out along the coastal line of Lake Baikal for the summer periods of 2014, 2016-2019.

\section{Material and methods}

The measurement data of five campaigns are considered, in which dissolved $\mathrm{CO}_{2}$ and $\mathrm{CH}_{4}$ were recorded at coastal hydrological stations and along the transition routes between them nearby the Baikal coast: August 5-11, 2014 southern Baikal, August 13-21, 2016 northern Baikal, July 14-20, 2017 middle Baikal,
August 15-23, 2018 southern and middle Baikal (with reference to settlements and tourist centres), August 10-19, 2019 Barguzinsky and Chivyrkuisky bays. The measurements were carried out by means of a measuring complex consisting of gas-analytical equipment, equilibrator, chamber for direct measurements of gas fluxes from a water surface (Pestunov et al., 2015). The carbon dioxide and methane contents in the atmosphere and water were measured using a Picarro G2301 gas analyzer. An equilibrator was used to transfer the dissolved gases contained in the water into the gas phase before being fed into the gas analyzer. Gas analysis equipment was mounted onboard the RV. A water sample was taken continuously from a depth of 0.3-0.5 meters. The "air-water" gas fluxes were measured using the chamber method only at hydrological stations.

\section{Results}

Since in this paper we consider the content of carbon dioxide and methane dissolved in water in the context of gas exchange processes with the atmosphere, it is convenient to present and compare data on the content of these gases in water and in the atmosphere in terms of partial pressure. By the difference in partial pressures, one can judge the direction and rate of gas emission into the atmosphere or its invasion by the water surface, and the available data array makes it possible to analyze the spatial and temporal distribution of their fluxes. 
Carbon dioxide. Along the entire perimeter of Baikal, a lower content of $\mathrm{CO}_{2}$ in water was observed compared with the atmosphere, its partial pressure in water almost never exceeded atmospheric one. Carbon dioxide is distributed in the water of the coastal zone of all basins quite uniformly, the largest variations of dissolved $\mathrm{CO}_{2}$ are mainly tied to the mouths of large rivers (Selenga, Barguzin, Kichera and others). Local increases in the content of dissolved carbon dioxide were repeatedly recorded in the vicinity of the coastline along the west coast, which were accompanied by a decrease in water temperature. This is probably due to the emergence of deep waters supersaturated with carbon dioxide. Excluding such cases, the average daily pattern of dissolved carbon dioxide throughout all measurement campaigns varies from 0.29 to $0.44 \mathrm{mgCO}_{2} / 1$ (average $\left.0.38 \mathrm{mgCO}_{2} / \mathrm{l}\right)$ i.e. it is less pronounced than in the BALO area (southern Baikal) for the same period, where the average concentration is noticeably higher $\left(0.57 \mathrm{mgCO}_{2} / 1\right.$ with a daily range of $0.355 \mathrm{mgCO}_{2} / \mathrm{l}$ ).

Methane. The partial pressure of methane in water always exceeded atmospheric one, and it varied many times from place to place along the coastline. Insignificant increase of methane partial pressure is observed at the approach to the coast (from 3-5 $\mu \mathrm{atm}$ at a distance of to $20 \mu \mathrm{atm}$ and higher at the coastline). In shallow bays, dissolved methane pressure reaches several hundred $\mu \mathrm{atm}$ and varied depending on the state of the bottom and geographic features of the area. High methane content in water was observed opposite river mouths (Anga, Barguzin, Turka, Selenga, etc.). In a large area of the northern tip of Lake Baikal and in the Chivyrkuisky Bay the methane content is hundreds of times higher than the minimum recorded values. Thus, the methane concentration along the coastline varies from 0.175 to $30 \mu \mathrm{gCH} / 1$ (in places up to 50 $\mu \mathrm{gCH}_{4} / 1$ ), while values exceeding $1.2 \mu \mathrm{gCH}_{4} / 1$ were rarely recorded in BALO.

\section{Discussion and conclusions}

For summertime, the partial pressure of carbon dioxide dissolved in water over almost the entire coastline is lower than in the atmosphere, right as in the BALO region. The average concentration for all campaigns was $0.38 \mathrm{mg} \mathrm{CO} / 1$, versus $0.57 \mathrm{mg} \mathrm{CO}_{2} / 1$ in BALO area. The daily pattern of dissolved $\mathrm{CO}_{2}$ recorded during RV campaigns was less pronounced than in the observatory. This is due to the fact that a significant part of the RV measurements was taken offshore, where the hydro-biological conditions are different than in the immediate vicinity of the shore. The methane content in water varies spatially from $0.175 \mu \mathrm{g} \mathrm{CH}_{4} / 1$ to $30 \mu \mathrm{g}$ $\mathrm{CH}_{4} / 1$ (Chivyrkuisky Bay), i.e. significantly different observational data in BALO, where the methane concentration varies in the range 0.175-1.2 $\mu \mathrm{g} \mathrm{CH}_{4} / \mathrm{l}$.

\section{Acknowledgments}

Long-term studies on Lake Baikal are carried out as was supported by the Ministry of Science and Higher Education of the Russian Federation - project No. AAAA-A17-117021310142-5 (IOA SB RAS), the project NIR 0345-2019-0008 (LIN SB RAS) and in 2018-2020 with partial financial support from the Russian Federal Property Fund and the Government of the Republic of Buryatia, joint project No. 18-45-030007

\section{References}

Panchenko M.V., Domysheva V.M., Pestunov D.A. et al. 2020. Carbon dioxide in the atmosphere-water system and biogenic elements in the littoral zone of Lake Baikal during period 2004-2018. Journal of Great Lakes Research 46: 85-94. DOI: $10.1016 /$ j.jglr.2019.10.016

Pestunov D.A., Shamrin A.M., Shmargunov V.P. et al. 2015. Gas-analytic measurement complexes of Baikal atmospheric-limnological observatory. Proceedings of SPIE 9680. DOI: $10.1117 / 12.2205538$ 